\title{
Studies on effect of biofertilizers with chemical fertilizers on growth, yield and quality of fenugreek (Trigonella foenum-graecum L.)
}

\author{
JITENDRA KUMAR MEENA, SANJAY KUMAR*, SUTANU MAJI, MANOJ KUMAR AND DEVENDRA \\ KUMAR \\ Department of Applied Plant Science (Horticulture), Babasaheb Bhimrao Ambedkar University, LUCKNOW (U.P.) \\ INDIA (Email : sanjay123bhu@gmail.com)
}

\begin{abstract}
The present investigation entitled studies on effect of bio-fertilizers with chemical fertilizers on growth, yield and quality of fenugreek (Trigonella foenum-graecum L.) was conducted at the Horticultural Research Farm, Department of Applied Plant Science (Horticulture), Babasaheb Bhimrao Ambedkar University, Lucknow (U.P.) during the years 2012-2013. Three bio- fertilizers viz., Azospirillum, PSB and Rhizobium were used at 2 levels of N, P and K as compared with control (recommended dose of NPK through chemical fertilizers) in the fenugreek. The result of all experiment showed that the maximum plant height $(36.84 \mathrm{~cm})$, number of branches (3.33), number of pods (7.20), days to 50 per cent flowering (66.33), days to 50 per cent germination (13.00) length of pods (8.53 cm), yield (15.57 q/ha), yield per plant (5.85 g) and days to maturity (145.26) were recorded under 50 per cent RDF+ 50 per cent Rhizobium whereas, minimum was recorded under control.
\end{abstract}

Key Words : RDF, Azospirillum, Rhizobium, Phosphate solubilizing bacteria (PSB), Fenugreek, Flowering, Maturity and yield.

View Point Article : Meena, Jitendra Kumar, Kumar, Sanjay, Maji, Sutanu, Kumar, Manoj and Kumar, Devendra (2015). Studies on effect of biofertilizers with chemical fertilizers on growth, yield and quality of fenugreek (Trigonella foenum-graecum L.). Internat. J. agric. Sci., 11 (1): 198200 .

Article History : Received : 28.10.2013; Revised : 15.12.2014; Accepted : 30.12.2014

\footnotetext{
* Author for correspondence
} 